
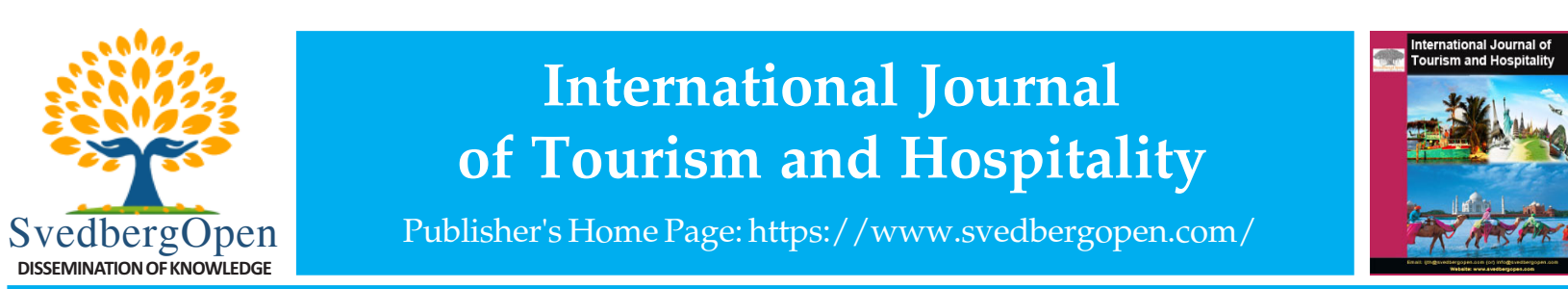

Research Paper

Open Access

\title{
Recent trends and future outlooks of tourists' sustainable behavior and sustainable development goals
}

\author{
WONG Chun Keung, Chris ${ }^{1 *}$ and HO Wing Sze, Anny ${ }^{2}$ \\ ${ }^{1}$ College of Professional and Continuing Education The Hong Kong Polytechnic University, Kowloon, Hong Kong Address: 9 Hoi Ting \\ Road, Yau Ma Tei, Kowloon, Hong Kong. E-mail: chris.wong@cpce-polyu.edu.hk \\ ${ }^{2}$ School of Hotel and Tourism Management The Hong Kong Polytechnic University, Kowloon, Hong Kong 17 Science Museum Road, \\ Tsim Sha Tsui, Kowloon, Hong Kong E-mail: anny.ws.ho@polyu.edu.hk
}

\section{Article Info}

Volume 1, Issue 3, July 2021

Received : 14 February 2021

Accepted : 12 June 2021

Published : 05 July 2021

doi: 10.51483/IJTH.1.3.2021.1-20

\begin{abstract}
This paper reviewed and analyzed peer-reviewed journals related to tourists' sustainable behavior and their contribution to the Sustainable Development Goals (SDGs) developed by the United Nations in the 2030 Agenda. Based on a keyword-driven search, 127 articles were identified as relevant from the selected journals and analyzed by content analysis with a pragmatic approach. The findings revealed that (a) the number of publications in this area had a downtrend except those focusing on 'attitudes'; (b) the geographical region of the articles mostly focused on few countries; (c) quantitative research methods were still dominant; and (d) around 58\% of the articles related to Goal 8, 11 and 12 of the SDGs. This paper discussed the above findings to illustrate the overall trends of this topic in academia and its limitation.
\end{abstract}

Keywords: Tourists'sustainable behavior, Sustainable development goals, SDGs, Sustainability.

(C) 2021 WONG Chun Keung, Chris and HO Wing Sze, Anny. This is an open access article under the CC BY license (https://creativecommons.org/licenses/by/4.0/), which permits unrestricted use, distribution, and reproduction in any medium, provided you give appropriate credit to the original author(s)and the source, provide a link to the Creative Commons license, and indicate if changes were made.

\section{Introduction}

The tourism industry is one of the central pillars of the world economy nowadays. From the world tourism barometer, the international tourist arrivals worldwide grew 4\% in 2019 to reach 1.5 billion (UNWTO, 2020). Apart from the contribution to the world economy, it brings along many issues that collectively known as 'overtourism'. It is defined as "the physical, psychological, economic and social capacity of a destination has been exceeded at a particular time" (Sharpley, 2020). However, the tourism industry was not included in the initial discussion of sustainable development of the world as a contributing factor to, nor a solution for, the problem. The World Commission on Environment and Development (WCED) first defined sustainable development in the Brundtland Report due to the environmental crisis that started affecting the living standard of humanity (WCED, 1987). It is defined as:

"....a process of change in which the exploitation of resources, the direction of investments, the orientation of technological development; and institutional change are all in harmony and enhance both current and future potential to meet human needs and aspirations" (WCED, 1987).

* Corresponding author: WONG Chun Keung, Chris, College of Professional and Continuing Education The Hong Kong Polytechnic University, Kowloon, Hong Kong Address: 9 Hoi Ting Road, Yau Ma Tei, Kowloon, Hong Kong. E-mail: chris.wong@cpce-polyu.edu.hk 
The Brundtland report is broadly addressed the overarching issue in terms of the pressure posting on the environment by the economic development and the consequences that may affect humanity in the near future. It also provided a new perspective of economic development should grow in harmony with the environment and society (Keong, 2016). To tackle the tourism issues causing by the ever-growing industry, tourism was internationally recognized as a contributing factor to sustainable development in the UN Conference on Environment and Development in 1992 (UN, 1992). Dang and Jamal (2016) presented a chronological evolution of sustainable development and sustainable tourism. It clearly stated that the definition of sustainable tourism was firstly introduced in 1994 by UNWTO and initiated the pledge to all governments and the tourism industry to engage in sustainable tourism practices. Since then, the United Nations took the lead to drive sustainable development programs (Mowforth and Munt, 2008). Furthermore, the Triple Bottom Line (TBL), i.e., environmental, sociocultural and economic, has been introduced to the theory of sustainability on top of the definition in 1994 by John Elkinton (Goebel et al., 2020).

The progress of the UN facilitation on sustainable development was recognized by the academic. Bäckstrand and Kylsäter (2014) found that the facilitation of the UN still strongly influencing the public-private partnerships in between the 2002 World Summit on Sustainable Development and the 2012 UN Rio+20 Summit. In 2015, the UN carried forward the efforts from the Millenium Sustainable Goals and further initiated the 2030 Agenda with 17 Sustainable Development Goals (SDGs) and 169 targets to aim for transforming the world until the year 2030 (UN, 2015). The SDGs and the related targets are claimed to "be integrated and indivisible and balance the three dimensions of sustainable development: the economic, social and environmental" (UN, 2015). The World Tourism Organization (UNWTO) responded actively to the initiative and explained the relationship of these SDGs with the tourism industry (UNWTO, 2015). It highlighted that tourism has a significant impact on three particular goals: "Decent work and economic growth" (8), "Responsible consumption and production" (12) and "Life below water" (14) (UNWTO, 2015). Since the publishing of SDGs, academia started investigating the relationship of the existing sustainable tourism practices to the underlying principles of SDGs and their related goals. Nevertheless, it is found that not all SDGs were equally investigated by academia since their publishment in 2015 (Rasoolimanesh et al., 2020). The dominant force of economic development to drive sustainable development reflected by Goal 8 of SDG, i.e., decent work and economic growth, is the most researched SDG from 2016 to 2018, followed by Goal 15 Life on land and Goal 3 Good health and well-being (Rasoolimanesh et al., 2020). A keyword search in Scopus with "SDGs" and "touris*" showed that the number of peer-reviewed journals in tourism studies that related to SDGs is proliferating from 2016 to 2020 (Figure 1). Within these 57 papers, the most popular topics are related to corporate social responsibility, hotel management, carbon footprint, and bibliometric and systemic literature review of sustainable tourism (Table 1). Other topics include quality education, ending poverty, small island destination development, government policy. The research trend has changed from a heavy focus on environmental sustainability to other social sustainable areas (Ruhanen et al., 2019). However, only one of the articles related to tourists' sustainable behavior, i.e. to engage the children, an essential stakeholder in tourism, in sustainability tourism education as a long-term transformational and behavioral-changing strategy (Seraphin et al., 2020).

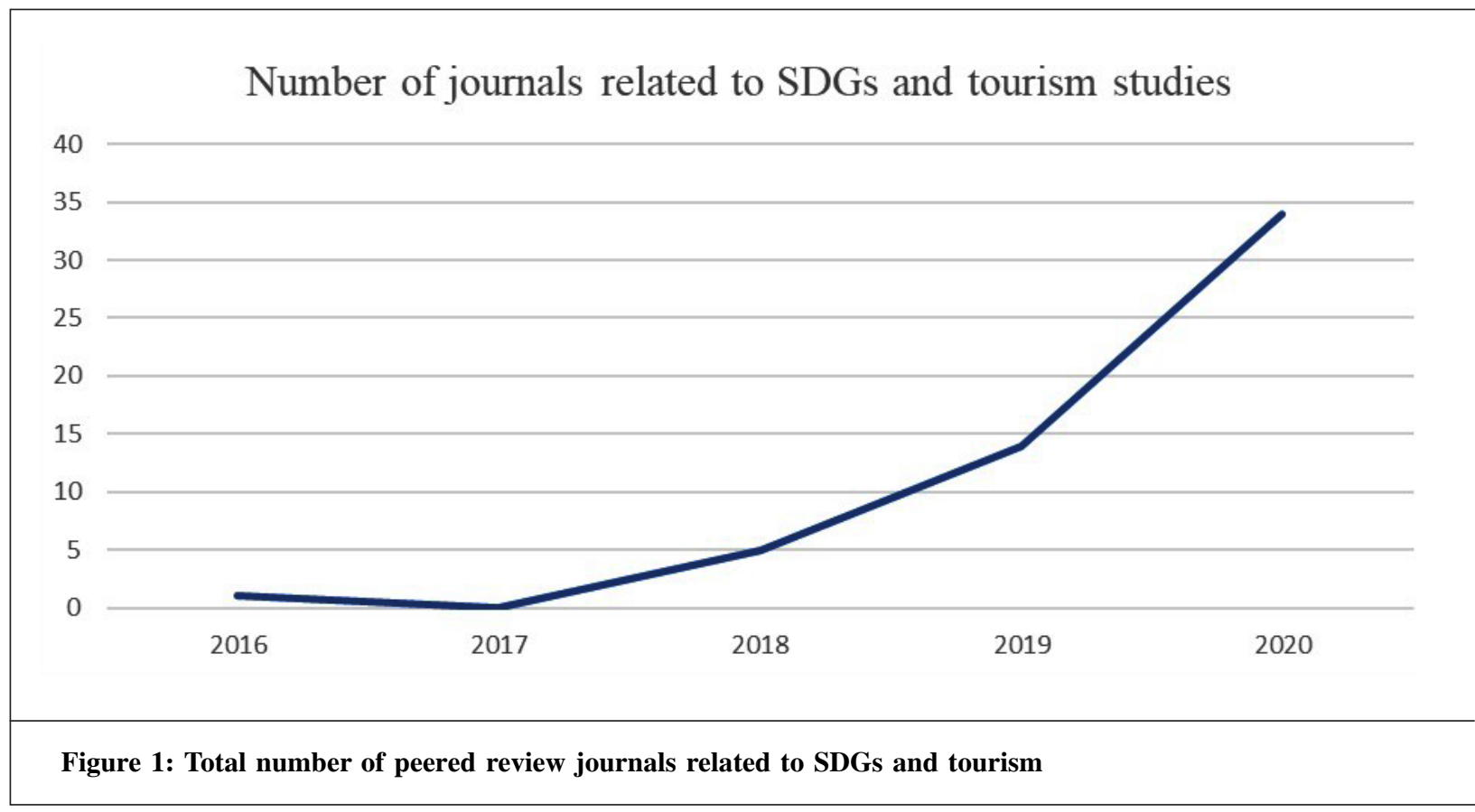


On the other hand, it is argued that any forms of alternative tourism will not exist if there are no tourists (Goodwin, 2011). Tourist is identified as one of the two stakeholders group by WTO (Byrd, 2007). Nevertheless, it is found that tourists to be the least engaged stakeholder group in many research related to sustainable tourism (Rasoolimanesh et al., 2020; Zolfani et al., 2015). Furthermore, academics regularly reviewed the research progress of specific topics. It contributes to the field with a comprehensive and thorough revision of that topic and forward-looking guidance of future research. Recently, many scholars have reviewed the literature of sustainable tourism development under different contexts, namely: sustainable tourism indicators, the competitiveness of the supply side, circular economy, resources consumption, digital sustainability, tourists' attitude, green dining (Boar et al., 2020; Della Corte et al., 2019; Moyle et al., 2020; Passafaro, 2020; Streimikiene et al., 2020; Del Gaudio et al., 2019; Higgins-Desbiolles et al., 2019; Zolfani et al., 2015). However, none of them is reviewing the overall tourists' sustainable behavior and only one review for the customer behavior in tourism within this decade (Cohen et al., 2014). Moreover, there were only 39 studies of behavior change from 1987 to 2017 (Moyle et al., 2020).

Table 1: Major categories of research topics related to SDGs from 2016-2020

\begin{tabular}{|c|c|c|}
\hline Category & Article title & Source \\
\hline \multirow[t]{5}{*}{$\begin{array}{l}\text { Corporate Social } \\
\text { Responsibility }\end{array}$} & $\begin{array}{l}\text { A research on the combination of oblique photography and } \\
\text { mobile applications based on the sustainable development of tourism }\end{array}$ & Lin, Li and Zhou (2020) \\
\hline & $\begin{array}{l}\text { Corporate social responsibility and organizational performance in } \\
\text { the tourism sector }\end{array}$ & $\begin{array}{l}\text { Moneva, Bonilla-Priego } \\
\text { and Ortas (2020) }\end{array}$ \\
\hline & $\begin{array}{l}\text { Exploring the applicability of sustainable development goals in } \\
\text { Costa Rica: case examples from Mastatal and Conchal. }\end{array}$ & Kandler Rodríguez (2020) \\
\hline & $\begin{array}{l}\text { Eco-innovative museums and visitors' perceptions of corporate } \\
\text { social responsibility }\end{array}$ & Chung, Tyan et al. (2018) \\
\hline & $\begin{array}{l}\text { Sustainability of Hotel, How Does Perceived Corporate Social } \\
\text { Responsibility Influence Employees' Behaviors? }\end{array}$ & $\begin{array}{l}\text { Kong, et al. } \\
\text { (2019) }\end{array}$ \\
\hline \multirow[t]{4}{*}{ Hotel Management } & $\begin{array}{l}\text { A description of green hotel practices and their role in } \\
\text { achieving sustainable development }\end{array}$ & Abdou, et al. (2020) \\
\hline & $\begin{array}{l}\text { A social-cognitive framework of small accommodation } \\
\text { enterprise sustainability practices }\end{array}$ & Agyeiwaah (2020) \\
\hline & $\begin{array}{l}\text { Fiction or reality? Hotel leaders' perception on climate action } \\
\text { and sustainable business models }\end{array}$ & $\begin{array}{l}\text { Dick-Forde, et al. } \\
\text { (2020) }\end{array}$ \\
\hline & $\begin{array}{l}\text { Sustainable development of mountain hotels through the } \\
\text { implementation of international management standards: } \\
\text { The Romanian case }\end{array}$ & $\begin{array}{l}\text { Firoiu, et al. } \\
\text { (2019) }\end{array}$ \\
\hline \multirow[t]{3}{*}{$\mathrm{CO}_{2}$ Emission } & $\begin{array}{l}\text { Dynamic linkages between tourism, technology and } \mathrm{CO}_{2} \text { emissions } \\
\text { in Pakistan }\end{array}$ & $\begin{array}{l}\text { Kumail, Ali, Sadiq, Wu } \\
\text { and Aburumman (2020) }\end{array}$ \\
\hline & $\begin{array}{l}\text { Decarbonising the Galapagos Islands: Techno-economic perspectives } \\
\text { for the hybrid renewable mini-grid Baltra-Santa Cruz }\end{array}$ & $\begin{array}{l}\text { Eras-Almeida, } \\
\text { et al. (2020) }\end{array}$ \\
\hline & $\begin{array}{l}\text { Tourism carbon footprint inventories: A review of the environmentally } \\
\text { extended input-output approach }\end{array}$ & Sun, Cadarso and Driml (2020) \\
\hline
\end{tabular}




\begin{tabular}{|c|c|c|}
\hline \multirow[t]{2}{*}{ Category } & Article title & Source \\
\hline & Tourism, environment and energy: an analysis for China & $\begin{array}{l}\text { Sharif, Saha, Campbell, } \\
\text { Sinha and Ibrahiem (2020) }\end{array}$ \\
\hline \multirow[t]{4}{*}{$\begin{array}{l}\text { Bibliometric and } \\
\text { Systematic Literature } \\
\text { Review }\end{array}$} & A bibliometric analysis of sports tourism and sustainability (2002-2019) & $\begin{array}{l}\text { Jiménez-García, Ruiz-Chico, } \\
\text { Peña-Sánchez and López- } \\
\text { Sánchez (2020) }\end{array}$ \\
\hline & $\begin{array}{l}\text { A systematic scoping review of sustainable tourism indicators in } \\
\text { relation to the sustainable development goals }\end{array}$ & $\begin{array}{l}\text { Rasoolimanesh, Ramakrishna, } \\
\text { Hall, Esfandiar and } \\
\text { Seyfi (2020) }\end{array}$ \\
\hline & $\begin{array}{l}\text { Are we really progressing sustainable tourism research? A bibliometric } \\
\text { analysis }\end{array}$ & $\begin{array}{l}\text { Moyle, Moyle, Ruhanen, } \\
\text { Weaver and Hadinejad (2020) }\end{array}$ \\
\hline & $\begin{array}{l}\text { Sustainable development goals and the strategic role of business: } \\
\text { A systematic literature review }\end{array}$ & Mio, Panfilo and Blundo (2020) \\
\hline
\end{tabular}

'Tourist behavior' is derived from the consumer behavior theories of the traditional marketing and management field (Cohen et al., 2014). Consumer behavior can be defined as a study of the decision-making process, i.e., from selection to post-purchase evaluation, over time with respect to marketing offering (Gupta and Singh, 2020). When adopting this definition by the tourism field, Moutinho (1987) has written a comprehensive theoretical analysis of the uniqueness of vacation tourist buying decision:

"The tourist buying decision presents some unique aspects: it is an investment with no tangible rate of return, and the purchase is often prepared and planned through savings made over a considerable period of time. That is, the vacation tourist will invest with no expectation of material and economic return on his or her purchase of an intangible satisfaction" (Moutinho, 1987, p. 5).

The vacation tourist behavior model developed by Moutinho (1987) segregated the buying decision process into three stages: the pre-decision and decision processes, post-purchase evaluation, and future decision making. Kotler $e t$ al. (2017) presented a model of consumer behavior in the hospitality and tourism industry, similar to the model proposed by Moutinho. To summarize these definitions and models, the tourist behavior includes internal and external stimuli, needs recognition, selection and acquisition, purchase, maintenance, evaluation and other post-purchase behaviors, and repeat buying probabilities (Gupta and Singh, 2020; Kotler et al., 2017; Moutinho, 1987). Nevertheless, critics of the existing research of consumer behavior are fragmented with the following causes (Cohen et al., 2014):

1. Many concepts are replica from marketing and general management fields to tourism;

2. Even investigating the same area of customer behavior, the results are not comparable due to the difference in research contexts, e.g., tourist types or destinations;

3. Quantitative approaches are not effective in quantifying the effect of independent stimuli in the buying process on behavioral responses dominate the research field, yielding erroneous causality effects;

4. Few studies use longitudinal and/or holistic approach to understand the behavior or processes because of tourist.

Fragmentation was also observed in the research of tourists' sustainable behavior. First of all, there is no consensus on the name of tourist behavior in sustainable tourism among researchers. Many research may use 'pro-environmental behavior' (Moghimehfar and Halpenny, 2016; Kim and Filimonau, 2017), 'ecotourism behavior' (Lee and Jan, 2018a, 2018b) and green behavior (Line et al., 2018; Paço et al., 2013). These names are implied that sustainable behavior is equivalent only to those behaviors related to environmental perspective, and other aspects of sustainable tourism, i.e. social, economic, cultural, political and ethical issues, are excluded (Moyle et al., 2020). In order to acknowledge other aspects of sustainable tourism, this study adopted 'tourists' sustainable behavior' suggested in the article of Passafaro (2020), which regard the tourists' choice and the action should be analyzed according to the definition of sustainability by UNWTO. 
As Moyle et al. (2020) suggested that sustainable tourism research should focus on how tourism can contribute to the overall sustainable development objectives, e.g., SDGs, this article evaluates the academic output of tourists' sustainable behavior by using the content analysis to summarize the contribution of academia on The 2030 Agenda for Sustainable Development. A pragmatic approach is adopted in this review because this paradigm offers a practical approach to evaluate the contribution.

\section{Methodology}

This paper adopted pragmatism as the philosophical stance and using content analysis as the tool to assess the knowledge from the existing literature. Pragmatism considers knowledge as "a tool for action such that the interpretation which enhances the capacity for positive change is favored by the researcher" (Flick, 2014). Although the Sustainability Development Goals Report 2020 sounds pessimistic about achieving the goal in the year 2030, the authors believe that any improvement towards the sustainability goals will lay a good foundation for the next initiative in sustainable development. This study aims to provide a clear summary and direction for future research to contribute to the SDGs. As tourism studies embracing origin from a wide variety of disciplines such as geography, economics, sociology etc., it is believed that 'mixed-methods' will be an emerging approach in tourism research if supporting by pragmatism as a philosophical paradigm that enhances the credibility of the methods adopted (Pansiri, 2005). Content analysis is chosen as it allows the data to be analyzed in mixed methods, i.e., qualitatively and quantitatively at the same time, and is suitable for exploratory work (Vaismoradi et al., 2013).

The first step was to select a database for data collection. Two rounds of data collection were performed between October and November 2020. The first round includes all related peer-reviewed articles from journals of the first and second quartile in Scopus, Web of Science (WoS) and Google Scholar from the year of 2016 to 2020, as The 2030 Agenda was published in late 2015 and many types of research regarding sustainable tourism proliferate after 2015 (Della Corte, 2019). However, the number of related articles was too large for the limited time frame. The second round of data collection limited the area of data collection to the four (4) tourism-focused journals, Tourism Management (TM), Journal of Travel Research (JTR), Annals of Tourism Research (ATR) and International Journal of Tourism Research (IJTR) in only one search engine, Scopus. The reason for choosing the first three journals is that their SJR scores are the top three based on the SJR indicator and have continued to play a vital role, contributing more to the theoretical rather than practical debate (Ruhanen et al., 2019). Although Current Issues in Tourism and Tourism Management Perspectives have higher SJR Indicators over IJTR, the rationale for choosing IJTR over these two journals is that IJTR has a higher percentage of international collaboration than the other two journals (SCImago, 2020). For the searching engine, Scopus is chosen over the two other search engines because it incorporates a more extensive collection of refereed literature than the other two (Rasoolimanesh et al., 2020).

The second step is refining the keyword search. As it is discovered that tourist behavior in sustainable tourism has various names, a generic term "tourism behavior" and the US spelling "tourism behavior" were initially used to avoid excluding any potentially related articles. Then, the keyword function in Scopus was utilized to refine the search. Fourteen extended keywords according to the UNWTO descriptors of the SDGs (Ruhanen et al., 2019). Afterwards, there were 129 articles shortlisted, including two review papers. The final number of articles is 127 from the year 2016 to November 2020. By referring to the SDGs descriptor, this will minimize the personal biases of the authors.

The next step was to analyze the content of the shortlisted articles. However, there is lacking an overall model of tourists' sustainable behavior to understand this topic better. The existing literature is dominated by the environmental area of the TBL of sustainable development. Do Paço et al. (2013) confirmed a green consumer behavior model by the quantitative method that established the value-attitude-behavior hierarchy and the relationship between attitudes and behavior. Recently, the attitude-behavior gap is one of the major research areas of tourists' sustainable behavior research (Fennell and Cooper, 2020). Several theories, e.g., the theory of planned-behavior, attitude-behavior gap, valuebelief-norm theory, have been deployed and tested through empirical research to understand how tourist' behavior can be influenced by the attitude in sustainable tourism (Denley et al., 2020; Ibnou-Laaroussi, 2020; Juvan and Dolnicar, 2014). However, mixed results were presented as having a positive attitude may not lead to actions. Budeanu (2007) proved that informative tools would only positively affect the attitude of tourists towards sustainable behavior but not the driving force of their behavioral change. Juvan and Dolnicar (2014) discovered that those participants used a wide range of explanations to justify their non-sustainable tourist behavior even they had a pro-environmental attitude. In order to have a better focus of the analysis, the nine key concepts in tourism consumer behavior summarized by Cohen et al. (2014) will be utilized to categorize the tourists' sustainable behavior described in the shortlisted articles. The nine key concepts are decision-making, values, motivations, self-concept and personality, expectations, attitudes, perceptions, 
satisfaction, and trust and loyalty. After the sample articles are categorized, the trend of these nine key concepts will be analyzed.

Therefore, the shortlisted articles will be analyzed in terms of the year of publication, geographical distribution, research methods, mapping of the articles to the SDGs and the number of articles according to the nine-key concepts in consumer behavior summarized by Cohen et al. (2014). The analysis will follow a discussion, and future research direction and limitation will be suggested.

\section{Findings and analysis}

\subsection{Overview of tourists sustainable behavior research}

The following descriptive findings are based on the final 127 articles identified for detailed synthesis. Our aim in this section is to showcase the development of the research area in terms of journals, publication output and frequency, geographic dispersion, authorship, methodology, and key findings in relations to Sustainable Developments Goals (SDGs) and Consumer Behavior (CB) concepts.

\begin{tabular}{|c|c|c|c|c|}
\hline Journal & $\begin{array}{l}\text { SCImago journal } \\
\text { rank (2019) }\end{array}$ & $\begin{array}{l}\text { Country of } \\
\text { publication }\end{array}$ & $\begin{array}{l}\text { Number of } \\
\operatorname{articles}(\mathbf{N})\end{array}$ & $\begin{array}{c}\text { Percentage in } \\
\text { total }(\%)\end{array}$ \\
\hline $\begin{array}{l}\text { Annals of Tourism } \\
\text { Research (ATR) }\end{array}$ & $2.228(\mathrm{Q} 1)$ & $\begin{array}{l}\text { United } \\
\text { Kingdom }\end{array}$ & 20 & 15.7 \\
\hline $\begin{array}{l}\text { International Journal } \\
\text { of Tourism Research } \\
(\text { IJTR })\end{array}$ & $1.032(\mathrm{Q} 1)$ & $\begin{array}{l}\text { United } \\
\text { Kingdom }\end{array}$ & 24 & 18.9 \\
\hline $\begin{array}{l}\text { Journal of Travel } \\
\text { Research }(J T R)\end{array}$ & $3.014(\mathrm{Q} 1)$ & $\begin{array}{l}\text { United } \\
\text { Kingdom }\end{array}$ & 31 & 24.4 \\
\hline $\begin{array}{l}\text { Tourism Management } \\
(T M)\end{array}$ & $3.068(\mathrm{Q} 1)$ & $\begin{array}{l}\text { United } \\
\text { Kingdom }\end{array}$ & 52 & 40.9 \\
\hline
\end{tabular}

The search resulted in a total of 127 articles. The journals from which articles were collected for analysis are presented in 'Table 2', together with their respective SCImago Journal Rank, the number of articles selected per journal, and the country of origin of the journal. The journal with the most relevant articles for this research is $\mathrm{TM}(\mathrm{N}=52$, $40.9 \%)$, followed by the JTR $(\mathrm{N}=31,24.4 \%)$, the IJTR $(\mathrm{N}=24,18.0 \%)$ and the ATR $(\mathrm{N}=20,15.7 \%)$.

\subsubsection{Publication by year}

Figure 2 presents the dispersion of publications across the period between 2016 and 2018. The literature search revealed that there had been a general decline in research output since 2018, despite the gradual increase of publications_from

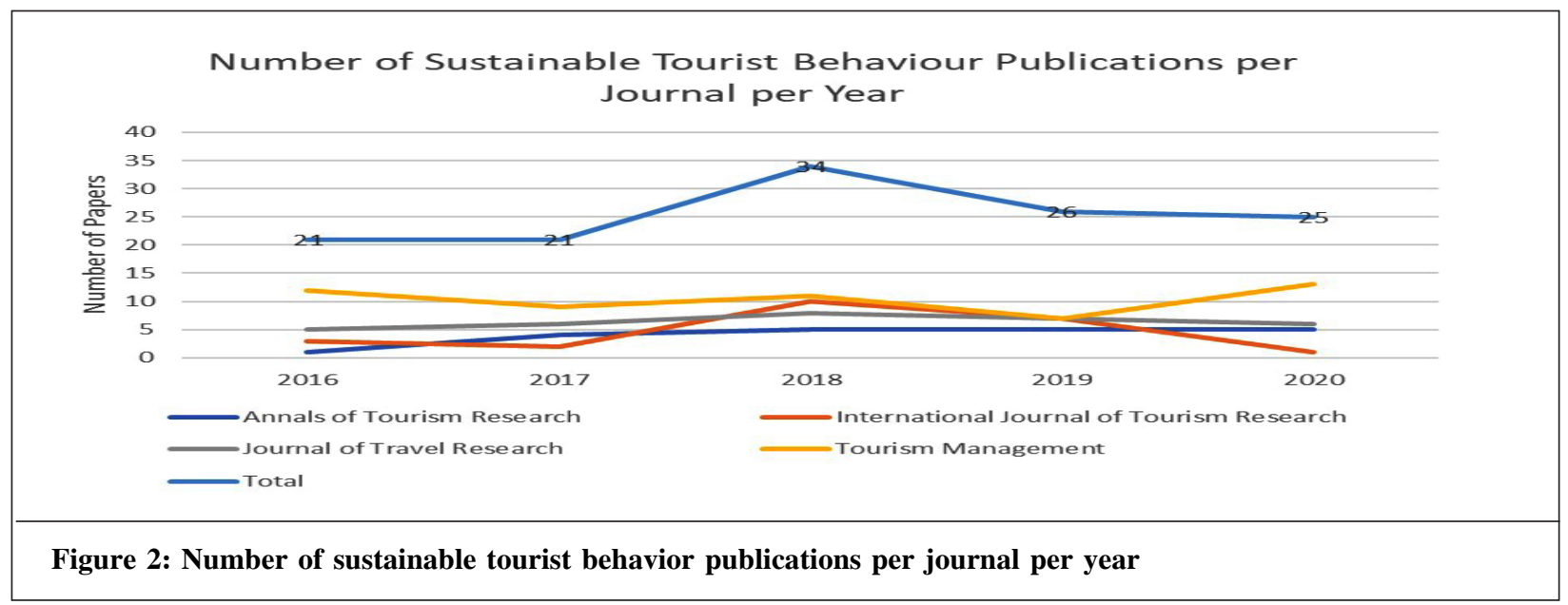


ATR. Since 2016, the ATR has published one paper, rising to four papers in 2017, five papers in 2018, and remained constant in 2019 and 2020. The publication rate in the JTR has remained steady in the last five years at an average of four papers per year, though it showed a downward trajectory from eight publications in 2018 to six publications in 2020. More than $40 \%$ of the articles published in TM have appeared in the past five years, with its highest output of thirteen publications in 2020. The publications from the IJTR varied from ten being the highest in 2018 and one being the lowest in 2020.

\subsubsection{Publication by geographical distribution}

'Figure 3' is a Pareto distribution showing the number of publications by country as determined by the locations of the author's institutions. Four countries, including the United States (US), United Kingdom, China, and Australia, account for nearly $50 \%$ of the articles selected on sustainable tourist behavior. The most frequently studied country was the US (38 papers).

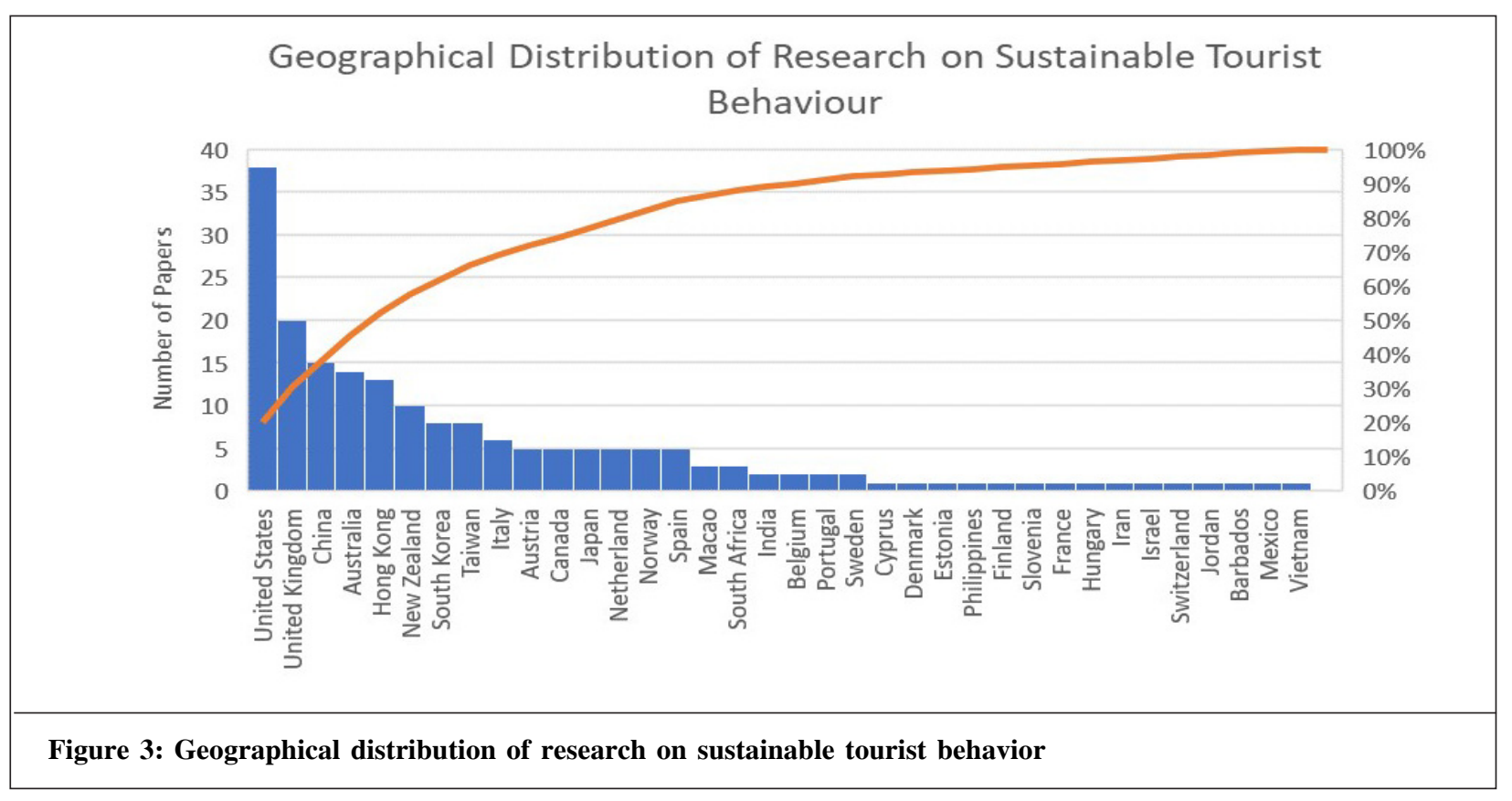

\subsubsection{Publication by research method}

'Table 3' presents an overview of the research method of the sample studies. The studies $(\mathrm{N}=86,67.7 \%)$ employed quantitative methods, followed by qualitative $=37,29.1 \%)$, and the mixed-method approach $(\mathrm{N}=4,3.1 \%)$, including quantitative qualitative methods. Overall, as seen in 'Figure 4,' more quantitative reviews were than qualitative reviews in the research focus of sustainable tourist behavior.

Table 3: Research methods in sustainable tourist behavior

\begin{tabular}{|l|c|c|}
\hline Research method & N & $\%$ \\
\hline Qualitative & 37 & 29.1 \\
\hline Quantitative & 86 & 3.1 \\
\hline Mixed Methods & 4 & \\
\hline Total & $\mathbf{1 2 7}$ & \\
\hline
\end{tabular}

\subsubsection{Publication by authorship}

'Table 4 ' indicates that $10.2 \%$ of publications were single-authored, $26.0 \%$ were produced by two authors, and $40.9 \%$ were produced by three authors; only $4.7 \%$ had more than five authors. Hence, triple authorship was the norm for sustainable tourist behavior publications during the five-year period. The same is reflected in 'Figure 5.' 


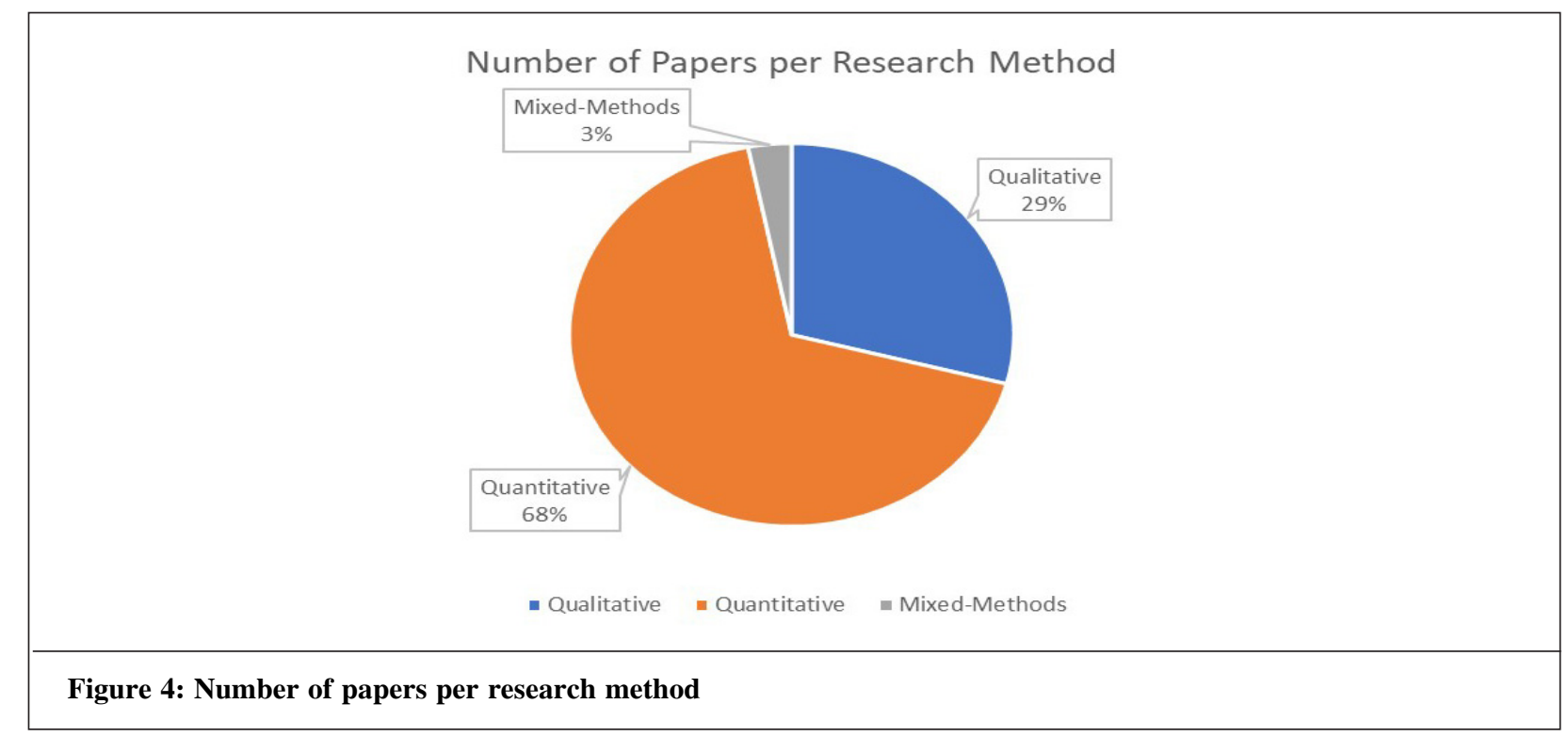

'Table 5' reflects a cohort of authorship in sustainable tourist behavior research in the five-year period, 2016-2020. It reviews that the trend for multi-author papers had consistently grown over the years. The mean number of authors per research publication grew from 2.375 in 2016 to 2.875 in 2020 . However, as reflected by 'Figure 6,' the increase in the

\begin{tabular}{|l|c|c|}
\hline Table 4: Number of authorship in sustainable tourist behaviour research \\
\hline Number of authors & Number of papers (N) & Percentage of total papers (\%) \\
\hline 1 & 13 & 10.2 \\
\hline 2 & 33 & 26.0 \\
\hline 3 & 52 & 40.9 \\
\hline 4 & 18 & 14.2 \\
\hline 5 & 5 & 3.9 \\
\hline More than five & 6 & 4.7 \\
\hline Total & $\mathbf{1 2 7}$ & \\
\hline
\end{tabular}

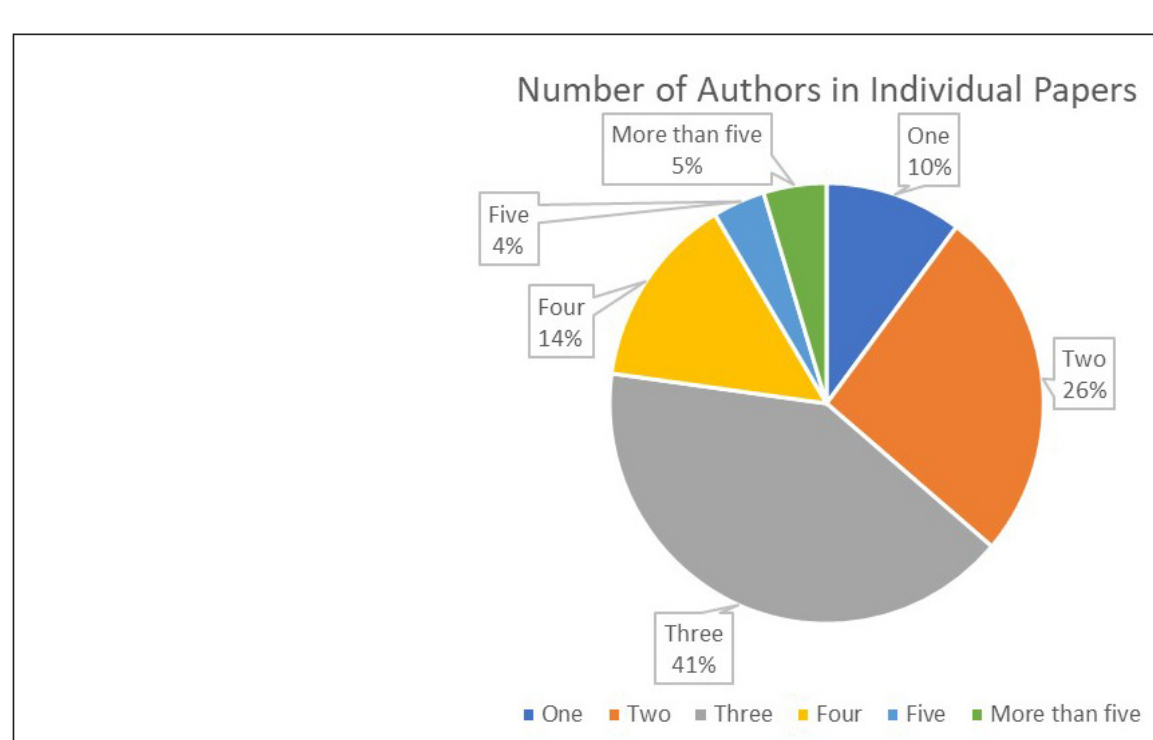


Table 5: Number of paper with multi-authorship in sustainable tourism research

\begin{tabular}{|l|c|c|c|}
\hline Year & Mean number of authors & Number of papers & Standard deviation \\
\hline 2016 & 2.375 & 19 & 4.912 \\
\hline 2017 & 2.375 & 19 & 3.655 \\
\hline 2018 & 3.875 & 31 & 4.390 \\
\hline 2019 & 2.750 & 22 & 3.852 \\
\hline 2020 & 2.875 & 23 & 2.973 \\
\hline $2016-20$ & & 127 & \\
\hline
\end{tabular}

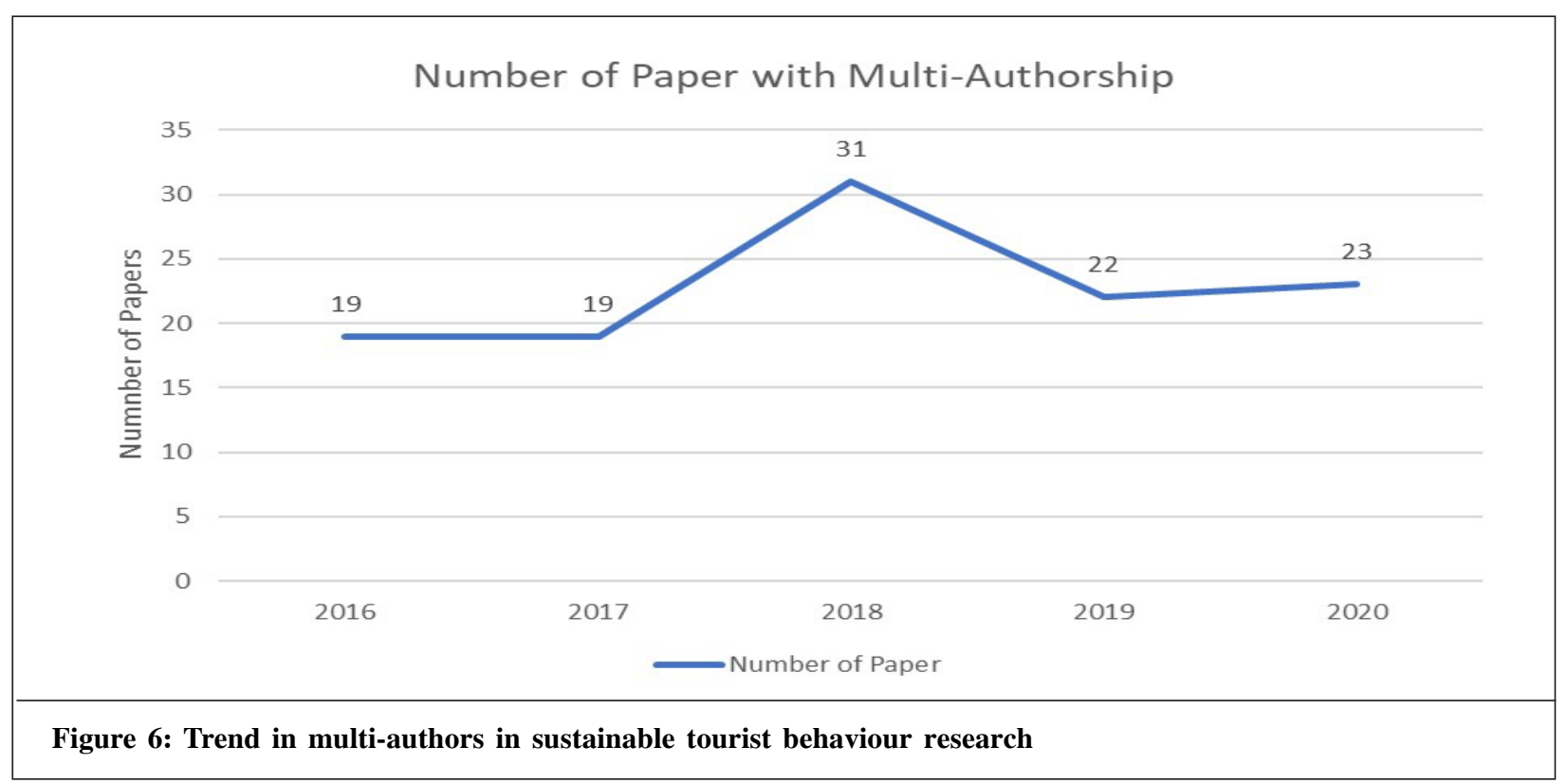

number of authors for individual papers was not consistent across the years; a minor drop in the number of research publications with multi-authors was noted in 2019.

\subsubsection{Publications by SDGs}

'Table 6' summarizes the frequency with which the papers reviewed in this study concerning the 17 SDGs. The SDG with the most publications was GOAL 8 "Decent Work and Economic Growth" with a little over 30 related articles, followed by GOAL 11 "Sustainable Cities and Communities" $(n=24)$ and GOAL 12 "Responsible Consumption and Production" (19). GOAL 7 "Affordable and Clean Energy" had the least amount of related publications, with only one article published.

The SDGs that experienced the most growth in terms of the number of publications were related to responsible consumption and sustainability. 'Figure 7' reviewed that GOAL 11 "Sustainable Cities and Communities" grew from three papers in 2018 to 8 papers in 2020, followed closely by GOAL 12 "Responsible Consumption and Production" grew from one article in 2017 to six articles in 2019. A significant drop in research interest was shown in GOAL 8 "Decent Work and Economic Growth" from ten papers in both 2016 and 2017 to two papers in 2020. Steadily rising in publication interests related to GOAL 14 "Life Below Water" is also shown in 'Figure 5' from one paper in 2018 to two papers in both years 2019 and 2020.

The SDGs that showed the strongest international collaboration, which means more than five international researchers working and authoring together, were related to responsible consumption, sustainability, and environmental issues. 'Table 4' exhibits that there are six papers that are published by more than five authors. Within these papers, papers regarding GOAL 3 "Good Health and Well-being" only feature 16.7\% $(\mathrm{N}=1)$ international collaborations. GOAL 11 "Sustainable Cities and Communities" showed $50 \%$ of papers $(\mathrm{N}=3)$ featuring international collaboration, followed by GOAL 12 "Responsible Consumption" ( $\mathrm{N}=2,33.3 \%)$ and GOAL 14 "Life Below Water" ( $=2,33.3 \%)$. 
Table 6: Number of papers with relevance to the SDGs

\begin{tabular}{|c|c|c|}
\hline SDGs & Number of papers applicable to SDGs (N) & Percentage of Total papers $(\%)$ \\
\hline GOAL 1: No Poverty & 0 & 0 \\
\hline GOAL 2: Zero Hunger & 0 & 0 \\
\hline GOAL 3: Good Health and Well-being & 5 & 3.9 \\
\hline GOAL 4: Quality Education & 0 & 0 \\
\hline GOAL 5: Gender Equality & 0 & 0 \\
\hline GOAL 6: Clean Water and Sanitation & 0 & 0 \\
\hline GOAL 7: Affordable and Clean Energy & 1 & 0.8 \\
\hline GOAL 8: Decent Work and Economic Growth & 31 & 24.4 \\
\hline GOAL 9: Industry, Innovation, and Infrastructure & 5 & 3.9 \\
\hline GOAL 10: Reduced Inequality & 0 & 0 \\
\hline GOAL 11: Sustainable Cities and Communities & 24 & 18.9 \\
\hline GOAL 12: Responsible Consumption and Production & 19 & 15.0 \\
\hline GOAL 13: Climate Action & 7 & 5.5 \\
\hline GOAL 14: Life below Water & 5 & 3.9 \\
\hline GOAL 15: Life on Land & 2 & 1.6 \\
\hline GOAL 16: Peace and Justice Strong Institutions & 7 & 5.5 \\
\hline GOAL 17: Partnerships to Achieve the Goals & 3 & 2.4 \\
\hline
\end{tabular}

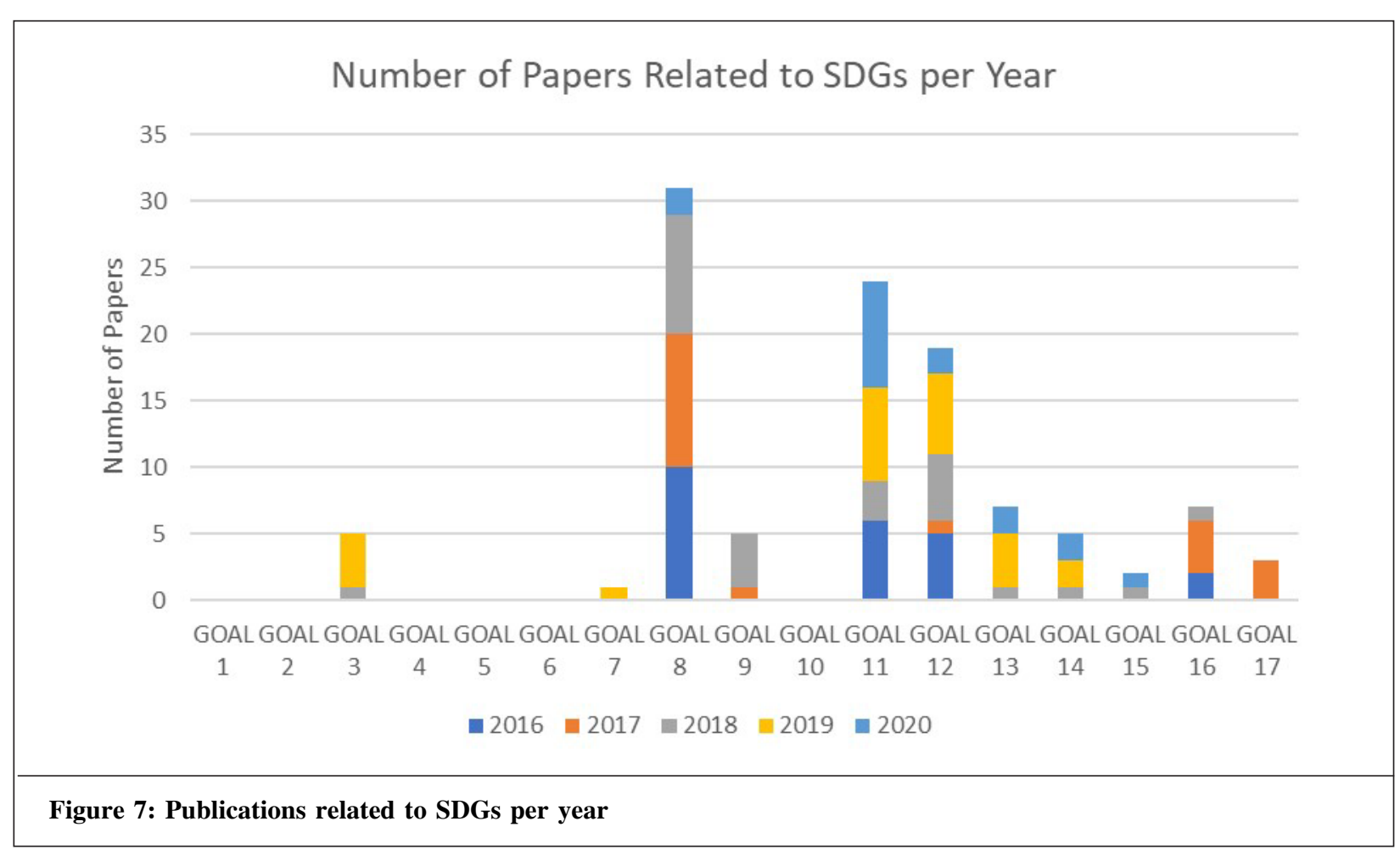




\subsubsection{Publications by consumer behavior concepts}

Based on the above findings, more than $50 \%$ of the articles reviewed are linked to GOAL 8 "Decent Work and Economic Growth," GOAL 11 "Sustainable Cities and Communities," and GOAL 12 "Responsible Consumption and Production." Therefore, publications that are linked to these 3 SDGs are chosen to study further. The nine key concepts in contemporary tourism consumer behavior research, proposed by Cohen et al. (2014), were used as a framework to assess the interactions with a view to the SDGs, precisely GOAL 8, 11, and 12; and the results are presented in 'Table 7.' Nineteen consumer behavior studies focusing on "Values" and "Satisfaction" have been published from 2016 to the present, followed by seventeen articles reviewing the concepts of "Expectations." The least frequently reviewed topic is "Trust and Loyalty" $(\mathrm{N}=6)$.

Table 7: Publications linked to SDGs 8, 11, and 12 per journal

\begin{tabular}{|c|c|c|c|c|c|}
\hline Key concepts & $\begin{array}{c}\text { Annals of } \\
\text { Tourism } \\
\text { Research } \\
\text { (ATR) }\end{array}$ & $\begin{array}{c}\text { International } \\
\text { Journal of } \\
\text { Tourism } \\
\text { Research (IJTR) }\end{array}$ & $\begin{array}{c}\text { Journal } \\
\text { of Travel } \\
\text { Research } \\
\text { (JTR) }\end{array}$ & $\begin{array}{c}\text { Tourism } \\
\text { Management } \\
\quad(T M)\end{array}$ & $\begin{array}{c}\text { Total } \\
\text { Number of } \\
\text { Articles }\end{array}$ \\
\hline Decision-making & 1 & 4 & 4 & 2 & 11 \\
\hline Values & 1 & 2 & 4 & 12 & 19 \\
\hline Motivations & 2 & 4 & 3 & 4 & 13 \\
\hline Self-concept and personality & 0 & 3 & 3 & 2 & 8 \\
\hline Expectations & 0 & 5 & 6 & 6 & 17 \\
\hline Attitudes & 1 & 0 & 4 & 4 & 9 \\
\hline Perceptions & 3 & 2 & 5 & 6 & 16 \\
\hline Satisfaction & 2 & 5 & 5 & 7 & 19 \\
\hline Trust and loyalty & 1 & 1 & 1 & 3 & 6 \\
\hline
\end{tabular}

Figure 8 shows the key concepts of CB research linked to GOAL 8, 11, and 12 from 2016 to 2020. Overall, the number of key concepts researched has dropped in the last two years. "Values," despite being one of the popular foci, the

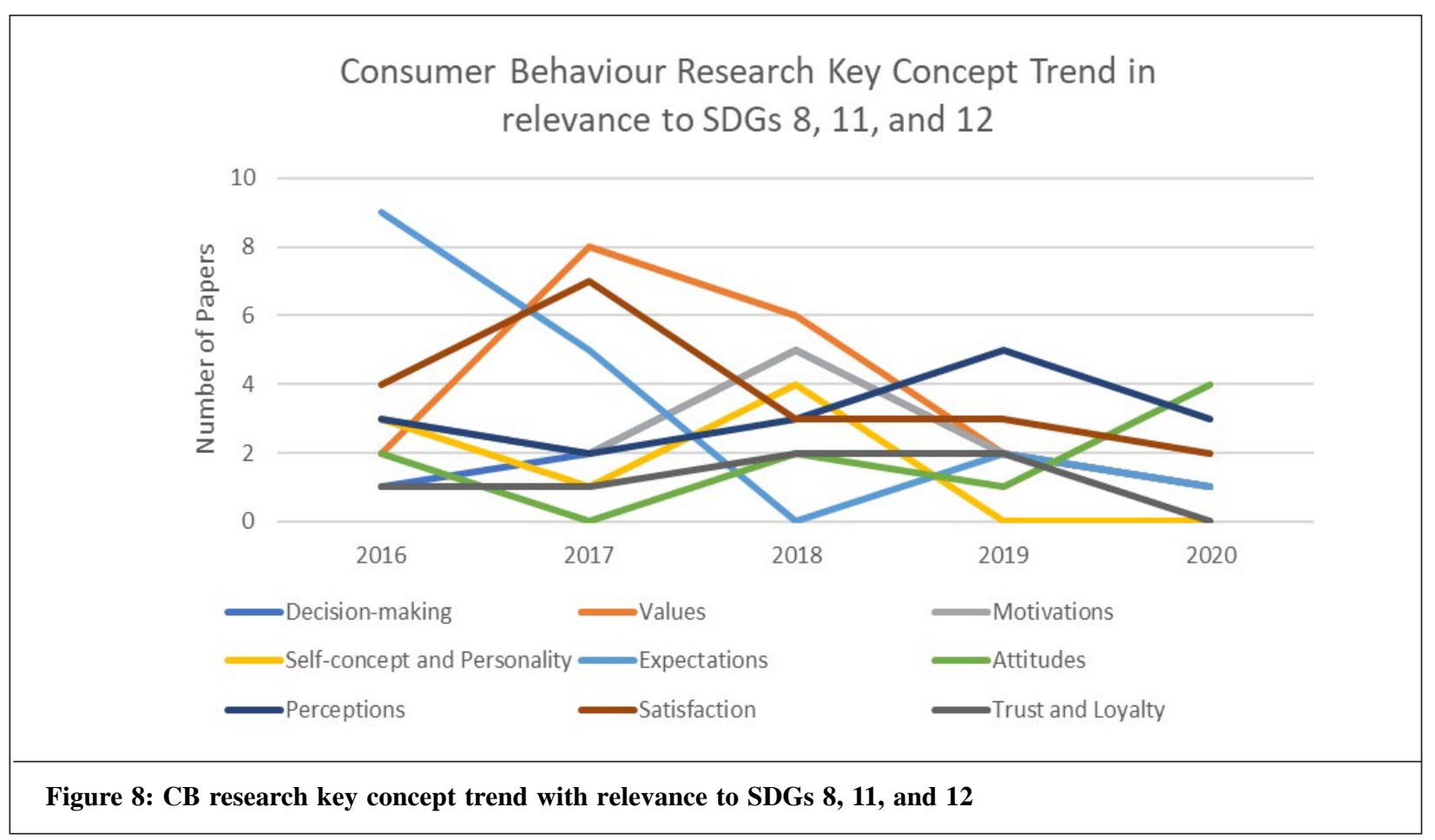


amount of output concerning this topic has decreased significantly from eight articles in 2017 to one article in 2020 . The same goes with articles related to "Expectations," which has gone down from nine outputs in 2016 to only one output in 2020. Interestingly, the least focused topic, "Trust and Loyalty," has shown a steady increase in interest from one article between 2016 and 2017 to 2 articles between 2018 and 2019. The number of studies concentrated in "Attitudes" published in 2020 increased to 4, double the amount from $2016(\mathrm{~N}=2)$. Notably, CB research related to "Self-Concept and Personality" has not been published since 2019 and has remained the same since.

\section{Discussions and implications}

This study presented a review of articles aimed at promoting tourists' sustainable behavior. Although the topic of sustainability has been an area of interest in the tourism context for over a decade, and 'visitor behavior and attitude' are in the top five highly discussed subject areas (Lu and Nepal, 2009), several issues emerge from our findings.

\subsection{Research intensity}

Our analysis shows that, primarily, how the focus of research has not tended towards tourists' sustainable behavior in the past two years. Although it might seem like it follows a clear negative trend in the overall number of publications, it did not necessarily indicate decreasing awareness and interest in the subject. This could be a result of swift from quantitative research to qualitative research, particularly using a longitudinal approach (Tracy, 2020). This echoes with the criticism from Cohen et al. (2014) that there are currently not enough longitudinal studies to understand tourist behavior. Researches have shown that longitudinal approaches are better detecting, examining, and monitoring patterns of change over time (Maruší et al., 2017; Polyhart and Vandenberg, 2010; Wong et al., 2017). Despite its challenges, including budget and time constraints, this approach can provide valuable information on the development of trends over time (Sæpórsdóttir and Hall, 2020). It is, therefore, relevant to show that the decrease in research intensity can be a result of changes in the study approach.

\subsection{Western hegemony}

Second, our analysis reveals that the majority of the researches are predominantly undertaken in the developed economies like the United States $(n=38,29.9 \%)$ and the United Kingdom $(n=20,15.7 \%)$. In part, this indicates several shortcomings in need of attention. For instance, most tourism is between the developed economies, and that tourism within the developing economies is still very minimal in extent. In addition, most tourism researchers are based in WEIRD countries (Henrich et al., 2010). This can be seen by the fact that all of the journals we reviewed in this study were published in journals from the United Kingdom, which may obstruct authors from non-English speaking countries (Gaertner, 2020). As such, it is not surprising that sustainable tourist behavior research could be construed as Western hegemony (Adams, 2003; Cater, 2006). In fact, among the developing countries in Asia, Africa, and Latin America, most of them need to tread dangerously between environmental conservation and livelihood fulfillment (Rasoolimanesh et al., 2020; Wall and Tao, 2008). It is, therefore, research in developing economies, especially those in Africa and South America, are still poorly represented.

\subsection{Research methods}

Third, our analysis corroborates previous research showing dominance in a quantitative research approach in the subject of sustainable tourism (Strandberg et al., 2016), and according to Cohen et al. (2014), this approach is not effective in looking at causality effects of one's behavioral response. Dwyer et al. (2012) included a comprehensive summary of various types of quantitative and qualitative methods, which are frequently used in tourism, in their edited book. For tourist behavior, it is always examined by statistical test techniques to confirmed the validity of hypotheses. However, some quantitative methods may have limitations in a specific context of tourist behavioral research. For example:

Econometric models: Cannot be used to analyze tourists' behavior because the model is not based on any economic theory that underlies tourists' decision-making processes.

Regression: Cannot take dynamic changes in tourists' behavior into consideration.

Structural Equation mModelling (SEM): Have the potential to violate the multivariate normality assumptions when using in an experimental design with randomly assigned participants and directly manipulated independent variables.

Tourism demand analysis: Not reliable when the variables have a minimal variation over time or new conditions that have not been validated in the past. 
As tourists' behavior is regarded as a continuous process that cannot always be analyzed separately, qualitative research is useful for a better understanding of tourist behavior (Tracy, 2020). For example, grounded theory can provide a holistic view and add more in-depth insight to studies using quantitative methodology when using mixed methods (Junek and Killion, 2012). McGehee et al. (2013) indicated that mixed-method studies are rarely put into practice in tourism, and in our study, the use of mixed methods in sustainable tourist behavior is somewhat insignificant $(\mathrm{N}=4$, $3.1 \%$ ). However, the use of mixed methods in tourism has been proposed from the perspectives of pragmatism (Pansiri, 2006). It is, therefore, important to know that the mixture of quantitative and qualitative outcomes that speak to different audiences by creating trust and transparency that leads to behavioral change (Molina-Azorin and Font, 2016). And this can be advantageous to the validity of sustainable tourist behavior research by allowing researchers to interrogate themselves (Thomas, 2004). For instance, many of the articles that we reviewed studied the 'green gap' in attitudebehavior (Fennell and Cooper, 2020), yet those researches that are done quantitatively and qualitatively show mixed and contradictory results (Dolnicar et al., 2008; Miller et al., 2010). Hence, it is clear that the combination of quantitative and qualitative research can help triangulate the results (Walker and Moscardo, 2014) so as to understand sustainability behavior critically.

\subsection{Research focus}

\subsubsection{GOAL 14}

Fourth, the evidence collected through our analysis has uncovered an inadequacy of consolidated literature about the GOAL 14 "Life Below Water" $(n=5,3.9 \%)$ - one of the SDGs identified by the UNWTO that has a significant impact on tourism. Thus, it is appropriate that researchers with a strong interest in the natural environment should study the relevance of this SDG and explore ways to sustainably use marine resources for sustainable development. Specifically, coastal areas, where so much tourism is concentrated, are pertinent given the increasing concerns about overcrowding in coastal destinations like Venice and Dubrovnik (Scheyvens, 2018).

\subsubsection{GOAL 8 and GOAL 11}

Furthermore, although most of the journals reviewed have presented a connection with GOAL 8 'Decent Work and Economic Growth,' the number of publications $(n=31,24.4 \%)$ in relevance to this SDG is decreasing in the past two years. This particular SDG initially seeks to focus on the promotion of "sustained, inclusive and sustainable economic growth" (UN, 2020), which according to Higgin-Desbiolles (2018), can be detrimental to tourism. So the concept of degrowth has become a popular subject among scholars (Kallis et al., 2018). This certainly helps explain the trajectory of the number of publications in relevance to GOAL 8 since 2018.

Hall (2019) criticized the SDGs and related goals as a failure to confront the norm in destination management as the success of the industry is deeply "rooted in the political and economic context of capitalistic resource extraction". In fact, the neoliberal discourse around the private sector, i.e., relying on the market mechanism in allocating resources, is still dominant and is suggested to be favorable for social inequalities (Scheyvens et al., 2016). For example, research emphasized the importance of governance to counteract the economic forces in the sustainable development of developing regions. Bushell (2018) had a straightforward narrative of the lack of governance in Laos caused poor performance of a variety of SDGs, e.g. poverty, natural resources exploitation, health and well-being, even it has the World Heritage status and enjoys a strong economic return from the tourism industry. However, this example showed Southeast Asian countries, especially those developing economies, may have difficulties achieving the SDGs. Other regions in the world that using tourism as a mean to end poverty may also need better governance to avoid the imbalance effect of neoliberal discourse. Folarin and Adeniyi (2020) verified that tourism could end poverty in the Saharan-Africa regions, but the prerequisite is to have a set of comprehensive government policies that will help the tourism industry to flourish and benefit the local communities. The policies include investing in infrastructure to facilitate international travel, promoting domestic participation of local poor residing in tourism by education and tourism policy planning, and marketing the destination to attract international arrivals. In fact, Folarin and Adeniyi have only discussed the governance of balancing the economic benefits and social development, but not environmentally sustainable, which is described as the most critical role of governance (Rasoolimanesh et al., 2020).

The above stance of neoliberal discourse is further proven by the actual performance reflected in the Sustainability Development Goals Report 2020. It is reported that the world as a whole was not on track to deliver its commitments to sustainable development by 2030 after four years of implementation (UN, 2020). For example, $22 \%$ of the world's young people were not in employment, education or training in 2019, a figure that has hardly changed since 2005 (UN, 2020). This result means Goal 8.6, which by 2020 substantially reduce the proportion of youth not in employment, education or 
training, is unmet (UN, 2015). Moreover, the projected target of the ultimate goal, i.e., ending poverty by 2030 , will be missed as the pace of global poverty reduction was decelerating before the Covid-19 pandemic (UN, 2020). Comparatively, the tourism industry has undergone tremendous growth in the past two decades. The total tourism expenditure increased from $\$ 763$ bn in 2005 to over $\$ 1.7$ tn in 2019 (The World Bank, 2020). As it is commented that the SDGs only focus on the economic contribution of tourism itself but not the distribution of income, it is questionable that by counting on the economic growth can hardly improve poverty (Goal 1) and job creation for youth (Goal 8) as promised by UNWTO (Hall, 2019; UNWTO, n.d.).

While GOAL 8 and its target focuses on economics, GOAL 11, "Sustainable Cities and Communities," and its target focuses on social objectives (Leal Filho et al., 2018). It can, therefore, be said that it fits into the approach of degrowth, which concentrates on change in the social system, for instance, the well-being of the communities (Hall and Gössling, 2013). Notions of this new approach include making transitions for improved livelihoods on a community-level (Cavaliere, 2017) and focusing on social sustainability (Robinson et al., 2019). Thus, this can explain why the number of papers related to GOAL $11(\mathrm{n}=24,18.9 \%)$ has the most noticeable increase in the past three years.

\subsubsection{Attitudes}

Last, in our analysis of leading tourism journals for the period 2016-2020, we have identified the trend of the key concepts in CB concerning tourists' sustainable behavior. Adopting the Cohen et al. (2014) framework, we mapped the nine key concepts of CB with the publications of tourists' sustainable behavior connected with SDGs 8, 11, and 12. Our results indicate that though "Values," "Satisfaction," and "Expectations" are the most frequently reviewed topics, "Attitudes" is the only concept that has doubled its appearances $(n=9)$ since 2016. It is undoubtedly that tourists nowadays yearn for more information about the availability of environmental travel options (Goodwin and Francis, 2003; Miller, 2003); however, it does not directly translate their desire to react to it or change their behavior in support of SDGs (Grankvist, 2002; Yan and Barkmann, 2006). The differences between attitudes and behavior (Leggett et al., 2003), and which, according to Fennell and Cooper (2020), is one of the major research areas in sustainable tourist behavior. Social desirability bias (Molina-Azorin and Font, 2016) can, therefore, provide the rationale behind the only increase in the number of outputs among all nine key concepts of CB.

\subsubsection{Micro vs macro}

The original objective of promoting sustainable tourism is reducing the negative impacts of mass tourism on the natural resources and socio-cultural aspects of the destinations (Mowforth and Munt, 2016). However, the sustainable solutions are commented to be a 'micro solution' to tackle a 'macro problem' which did not seem fit (Clarke, 1997; Sharpley, 2020). Jamal (2013) commented that the responsible tourism initiatives that emerged in the 1980s had a micro-level focus with an unclear focus on justice and ethics and required an integrated micro-macro approach to build a new sustainable tourism paradigm with fair and ethical practices in resource conservation. The 2030 Agenda and SDGs answered the call from Jamal as it focuses more on the macro-level issues, i.e., governance and poverty.

The trend of focusing on the macro-level issues by academia was also observed in Table 1 that sustainable tourism research related to the SDGs are following this trend. This trend may slow down the investigation on micro-level issues like tourist behavior, which usually remained on an individual level (Laing and Frost, 2017; Trinh and Ryan, 2017). The integrated micro-macro approach of sustainable tourism is suggested to be influential in understanding tourism behavior, which is supported by Wong et al. (2017). As consumption behavior in marketing theory is regarded on a micro level as it is connected to personal needs, wants, and satisfaction, both micro- (individual level, e.g. demographic) and macrolevel (economic fluctuation) factors will influence the outbound tourist consumption behavior over time (Wong et al., 2017; Kilborune et al., 1997). As mentioned in the previous section, attitude may not be enough to understand tourists' sustainable behavior. Future research may incorporate the micro-macro model to better understand the factors that shape tourists' sustainable behavior from different levels.

\section{Limitations and future research}

Despite the contribution of the present analytical review to sustainable tourist behavior research, there are some limitations. The first limitation concerns the fact that it only includes the four tourism journals. To begin with, these journals were chosen because they are seen as top journals in the tourism field. Yet, it should be noted that some studies might have been printed in other respectable journals, especially those journals with a more specific focus on sustainability like the Journal of Sustainable Tourism and Sustainability. This may enable us to judge more accurately where our discipline stands in terms of sustainable tourist behavior. In addition, because the authors only focused on tourism 
journals, articles in hospitality journals were neglected in this study. Though the hospitality and tourism industries intertwined in many ways, these two industries "are neither identical nor interchangeable" (Pizam, 2009). While tourism is an industry made up of good and services provided by hospitality firms, the fact that the very same hospitality businesses also offer good and services to non-tourists revealed the limitation of this current study regarding sustainable behaviors. As a result, further examination of tourists' sustainable behavior research in hospitality publications should be conducted in the future.

Second, there were also other forms of publications available, albeit not included in this study, such as reference books, conference proceedings, and magazine publications. One could argue that the present review is not exhaustive but comprehensive. A broader range of review would undoubtedly enhance the validity of the current findings.

Third, another hindrance might be related to time. According to García et al. (2018), time is needed for a publication to make a difference within the field. Our findings reveal that the "longitudinal" approach and the concept of "Attitudes" in tourist's sustainable behavior have been drawing attention by scholars since 2018. Therefore, the insufficiency of such studies is justifiable.

Last but not least, due to the interdisciplinary nature of tourism, some of the authors might have their research articles published in journals of other fields (Ashraf et al., 2020; Budeanu, 2007). Given the increasing interest in social desirability bias, it would be intriguing to examine the status of the attitude-behavior gap in sustainable tourism several years from now. One could also broaden the scope of this paper by including other related fields such as psychology, sociology and general business journals and do a comparative study.

\section{Conclusion}

This study aims to give a critical review concerning tourists' sustainable behavior. In doing so, 127 peer-reviewed articles were selected and analyzed based on their journals, publication output and frequency, geographic dispersion, authorship, and methodology. Moreover, the analytical review mapped the studies in relation to the SDGs and the key concepts of consumer behavior. Overall, the research reviewed tourism-focused papers that were published between 2016 and 2020. This paper answered the research question, "what is the recent contribution of academia in the area of tourists' sustainable behavior to the development of SDGs?".

Firstly, for the research method and geographies, it is observed that the studies with quantitative methods and in western developed countries, especially the US and UK, were concentrated in recent years. The reduction of publications in tourist' sustainable behavior may cause by a shift to qualitative research and longitudinal studies, which has been suggested by the academics. Moreover, the focus of publications related to SDGs and tourism is shifting to macro-level issues, e.g. ending poverty, the locations of the tourists' sustainable behavior studies may be redirected to the developing regions. Secondly, for the research focus, SDG 14 is still under-evaluated compared to the SDG 8 and SDG 11, which were the main focus with greater attention. It is encouraged that tourism researchers collaborate with experts in marine studies to uncover more knowledge on the impact of tourists' sustainable behavior in relation to marine life. Thirdly, the recent focus of the nine key concepts is "Attitudes", which has been described as an essential factor for tourist behavior. Although the concepts of tourist' behavior are fragmented, it is shown that the growth rate of publication of this factor has been doubled in recent years. It is expected that the mediators and moderators of attitude will be further studied to close the attitude-behavior gap. The limitation of this article encouraged further reviews of this area in other journals in a cross-disciplinary approach.

\section{Conflicts of Interest}

No conflict exists in this review paper.

\section{Acknowledgment}

Not applicable

\section{References}

Abdou, Ahmend, Hassan., Hassan, Thowayeb, Hassan. and El Dief, Mohammed. (2020). A description of green hotel practices and their role in achieving sustainable development. Sustainability (Basel, Switzerland), 12(9624), 9624. https://doi.org/10.3390/su12229624

Adams, William, Mark. (2003). Green Development: Environmental and Sustainability in the Third World. Taylor and Francis. https://doi.org/10.4324/9780203440896 
Agyeiwaah, Elizabeth. (2020). A social-cognitive framework of small accommodation enterprise sustainability practices. International Journal of Tourism Research, 22(5), 666-676. https://doi.org/10.1002/jtr.2364

Ashraf, Muhammad Saeed, Hou, Fujun, Kim, Woo Gon, Ahmad, Wasim. and Ashraf, Rana Umair. (2020). Modeling tourists' visiting intentions toward ecofriendly destinations: Implications for sustainable tourism operators. Business Strategy and the Environment, 29(1), 54-71. https://doi.org/10.1002/bse.2350

Bäckstrand, Karin. and Kylsäter, Mikael. (2014). Old Wine in New Bottles? The Legitimation and Delegitimation of UN Public-Private Partnerships for Sustainable Development from the Johannesburg Summit to the Rio+20 Summit. Globalizations, 11(3), 331-347. https://doi.org/10.1080/14747731.2014.892398

Boar, Andrei, Bastida, Ramon. and Marimon, Frederic. (2020). A systematic literature review. Relationships between the sharing economy, sustainability and sustainable development goals. Sustainability (Switzerland), 12(17). https:/ /doi.org/10.3390/SU12176744

Budeanu, Adriana. (2007). Sustainable tourist behaviour - a discussion of opportunities for change. International Journal of Consumer Studies, 31(5), 499-508. https://doi.org/10.1111/j.1470-6431.2007.00606.x

Cater, Erlet. (2006). Ecotourism as a western construct. Journal of Ecotourism, 5(1-2), 23-39. https://doi.org/10.1080/ 14724040608668445

Cavaliere, Christina T. (2017). Cultivating Climate Consciousness: Agritourism Providers' Perspectives of Farms, Food and Place (Doctoral dissertation, University of Otago).

Chung, Namho, Lee, Hyunae, Kim, Jin-Young. and Koo, Chulmo. (2018). The role of augmented reality for experienceinfluenced environments: the case of cultural heritage tourism in Korea. Journal of Travel Research, 57(5), 627643. https://doi.org/10.1177/0047287517708255

Clarke, Jackie. (1997). A framework of approaches to sustainable tourism. Journal of Sustainable Tourism, 5(3), $224-233$. https://doi.org/10.1080/09669589708667287

Cohen, Scott A, Prayag, Girish. and Moital, Miguel. (2014). Consumer behaviour in tourism: Concepts, influences and opportunities. Current Issues in Tourism, 17(10), 872-909. https://doi.org/10.1080/13683500.2013.850064

Della Corte, Valentina, Del Gaudio, Giovanna, Sepe, Fabiana. and Sciarelli, Fabiana. (2019). Sustainable tourism in the open innovation realm: A bibliometric analysis. Sustainability (Basel, Switzerland), 11(21), 6114. https://doi.org/ $10.3390 /$ su11216114

Denley, Tara J, Woosnam, Kyle Maurice, Ribeiro, Manuel Alector, Boley, B. Bynum, Hehir, Christy. and Abrams, Jesse. (2020). Individuals' intentions to engage in last chance tourism: applying the value-belief-norm model. Journal of Sustainable Tourism, 28(11), 1860-1881. https://doi.org/10.1080/09669582.2020.1762623

Dick-Forde, Emily Gaynor, Oftedal, Elin Merethe. and Bertella, Giovanna Merethe. (2020). Fiction or reality? Hotel leaders' perception on climate action and sustainable business models. Worldwide Hospitality and Tourism Themes, 12(3), 245-260. https://doi.org/10.1108/WHATT-02-2020-0012

Dolnicar, Sara, Crouch, Geoffrey I. and Long, Patrick. (2008). Environment-friendly tourists: what do we really know about them? Journal of Sustainable Tourism, 16(2), 197-210. https://doi.org/10.2167/jost738.0

Dwyer, Larry, Gill, Alison. and Seetaram, Neelu. (2012). Handbook of Research Methods in Tourism: Quantitative and Qualitative Approaches. Edward Elgar Publishing. https://doi.org/10.4337/9781781001295

Eras-Almeida, Andrea A, Egido-Aguilera, Miguel A, Blechinger, Philipp, Berendes, Sarah, Caamaño, Estefanía. and García-Alcalde, Enrique. (2020). Decarbonizing the galapagos islands: techno-economic perspectives for the hybrid renewable mini-grid baltra-santa cruz. Sustainability (Basel, Switzerland), 12(6). https://doi.org/10.3390/ su12062282

Fennell, David A. and Cooper, Chris. (2020). Sustainable tourism: principles, contexts and practices (Vol. 6). Channel View Publications.

Firoiu, Daniela, Ionescu, George H, Bãdîrcea, Roxana, Vocha, Lumini^a. and Enescu, Maria. (2019). Sustainable development of mountain hotels through the implementation of international management standards: The Romanian case. Sustainability (Basel, Switzerland), 11(22). https://doi.org/10.3390/su11226487

Flick, Uwe. (2014). Implementation: Putting analyses into practice. In The SAGE Handbook of Qualitative Data Analysis (p. 585). SAGE Publications Ltd. https://doi.org/10.4135/9781446282243.n40 
Folarin, Oludele. and Adeniyi, Oluwatosin. (2020). Does tourism reduce poverty in sub-saharan african countries? Journal of Travel Research, 59(1), 140-155. https://doi.org/10.1177/0047287518821736

Gaertner, Suzanne. (2020). The struggle is real - surviving in an english-speaking scientific world. Retrieved from https:/ /www.wiley.com/network/archive/the-struggle-is-real-surviving-in-an-english-speaking-scientific-world

García-Lillo, Francisco, Claver-Cortés, Enrique, Úbeda-García, Mercedes, Marco-Lajara, Bartolomé. and Zaragoza-Sáez, Patrocinio Carmen. (2018). Mapping the 'intellectual structure' of research on human resources in the 'tourism and hospitality management scientific domain'. International Journal of Contemporary Hospitality Management, 30(3), 1741-1768. https://doi.org/10.1108/IJCHM-04-2017-0187

Goodwin, Harold. (2011). Taking responsibility for tourism responsible tourism management. Goodfellow Publishers, Ltd.

Goodwin, Harold. and Francis, Justin. (2003). Ethical and responsible tourism: Consumer trends in the UK. Journal of Vacation Marketing, 9(3), 271-284. https://doi.org/10.1177/135676670300900306

Grankvist, Gunne. (2002). Determinants of choice of eco-labeled products. Department of Psychology, Göteborg University, Sweden.

Gupta, Karnika. and Singh, Narendra. (2020). Consumption Behaviour and Social Responsibility: A Consumer Research Approach. Springer Singapore Pte. Limited.

Hall, Gössling, Hall, Colin Michael. and Gössling, Stefan. (2013). Sustainable Culinary Systems: Local Foods, Innovation, and Tourism \& Hospitality. Routledge.

Henrich, Joseph, Heine, Steven J. and Norenzayan, Ara. (2010). The weirdest people in the world?. The Behavioral and Brain Sciences, 33(2-3), 61-83. https://doi.org/10.1017/S0140525X0999152X

Higgins-Desbiolles, Freya. (2018). Sustainable tourism: Sustaining tourism or something more?. Tourism Management Perspectives, 25, 157-160. https://doi.org/10.1016/j.tmp.2017.11.017

Higgins-Desbiolles, Freya, Moskwa, Emily. and Wijesinghe, Gayathri. (2019). How sustainable is sustainable hospitality research? A review of sustainable restaurant literature from 1991 to 2015. Current Issues in Tourism, 22(13), 15511580. https://doi.org/10.1080/13683500.2017.1383368

Junek, Olga \& Killion, Les. (2012). Grounded Theory. In Handbook of Research Methods in Tourism. (pp. 325-338) Edward Elgar Publishing. https://doi.org/10.4337/9781781001295.00022

Juvan, Emil. and Dolnicar, Sara. (2014). The attitude-behaviour gap in sustainable tourism. Annals of Tourism Research, 48, 76-95. https://doi.org/10.1016/j.annals.2014.05.012

Keong, Choy Yee. (2016). Economic growth, sustainable development and ecological conservation in the asian developing countries: the way forward. In Naturalists, Explorers and Field Scientists in South-East Asia and Australasia (pp. 239-283). Springer International Publishing. https://doi.org/10.1007/978-3-319-26161-4_16

Kotler, Bowen, Makens, Bowen, John. and Makens, James C. (2017). Marketing for hospitality and tourism (Seventh edition, Global edition.). Pearson.

Laing, Jennifer H.. and Frost, Warwick. (2017). Journeys of well-being: Women's travel narratives of transformation and self-discovery in Italy. Tourism Management (1982), 62, 110-119. https://doi.org/10.1016/j.tourman.2017.04.004

Lee, Tsung Hung. and Jan, FenHauh. (2018a). Development and validation of the ecotourism behavior scale. The International Journal of Tourism Research, 20(2), 191-203. https://doi.org/10.1002/jtr.2172

Lee, Tsung Hung. and Jan, FenHauh. (2018b). Ecotourism behavior of nature-based tourists: an integrative framework. Journal of Travel Research, 57(6), 792-810. https://doi.org/10.1177/0047287517717350

Lin, Li-Pin, Huang, Shu-Chun. and Ho, Yao-Chun. (2020). Could virtual reality effectively market slow travel in a heritage destination? Tourism Management (1982), 78, 104027. https://doi.org/10.1016/j.tourman.2019.104027

Line, Nathaniel D, Hanks, Lydia. and Miao, Li. (2018). Image matters: incentivizing green tourism behavior. Journal of Travel Research, 57(3), 296-309. https://doi.org/10.1177/0047287517697848

Liu, Zhenhua. (2003). Sustainable tourism development: A critique. Journal of Sustainable Tourism, 11(6), 459-475. https://doi.org/10.1080/09669580308667216 
Marušiæ, Zrinka, Sever, Ivan. and Èorak, Sanda. (2017). Identifying trends in tourism demand using longitudinal survey. In Evolution of Destination Planning and Strategy (pp. 221-243). Springer International Publishing AG.

Miller, Graham A. (2003). Consumerism in sustainable tourism: A survey of UK consumers. Journal of Sustainable Tourism, 11(1), 17-39. https://doi.org/10.1080/09669580308667191

Miller, Graham, Rathouse, Kathryn, Scarles, Caroline, Holmes, Kirsten. and Tribe, John. (2010). Public understanding of sustainable tourism. Annals of Tourism Research, 37(3), 627-645. https://doi.org/10.1016/j.annals.2009.12.002

Moghimehfar, Farhad. and Halpenny, Elizabeth A. (2016). How do people negotiate through their constraints to engage in pro-environmental behavior? A study of front-country campers in Alberta, Canada. Tourism Management (1982), 57, 362-372. https://doi.org/10.1016/j.tourman.2016.07.001

Molina-Azorín, José F. and Font, Xavier. (2016). Mixed methods in sustainable tourism research: an analysis of prevalence, designs and application in JOST (2005-2014). Journal of Sustainable Tourism, 24(4), 549-573. https://doi.org/ 10.1080/09669582.2015.1073739

Moutinho, Luiz. (1987). Consumer behaviour in tourism. European Journal of Marketing, 21(10), 5-44. https://doi.org/ 10.1108/eum0000000004718

Mowforth, Martin \& Munt, Ian. (2008). Tourism and Sustainability - Development, Globalisation and New Tourism in the Third World. Taylor and Francis. https://doi.org/10.4324/9780203891056

Moyle, Brent, Moyle, Char-lee, Ruhanen, Lisa, Weaver, David. and Hadinejad, Arghavan. (2020). Are we really progressing sustainable tourism research? A bibliometric analysis. Journal of Sustainable Tourism, 29(1), 106-122. https:// doi.org/10.1080/09669582.2020.1817048

Paço, Arminda, Alves, Helena, Shiel, Chris. and Filho, Walter Leal. (2013). Development of a green consumer behaviour model. International Journal of Consumer Studies, 37(4), 414-421. https://doi.org/10.1111/ijcs.12009

Pansiri, Jaloni. (2005). Pragmatism: A methodological approach to researching strategic alliances in tourism. Tourism and Hospitality Planning \& Development, 2(3), 191-206. https://doi.org/10.1080/14790530500399333

Pansiri, Jaloni. (2006). Doing tourism research using the pragmatism paradigm: an empirical example. Tourism and Hospitality Planning \& Development, 3(3), 223-240. https://doi.org/10.1080/14790530601132401

Passafaro, Paola. (2020). Attitudes and tourists' sustainable behavior: an overview of the literature and discussion of some theoretical and methodological issues. Journal of Travel Research, 59(4), 579-601. https://doi.org/10.1177/ 0047287519851171

Pizam, Abraham. (2009). What is the hospitality industry and how does it differ from the tourism and travel industries? International Journal of Hospitality Management, 28(2), 183-184. https://doi.org/10.1016/j.ijhm.2009.01.001

Ployhart, Robert E. and Vandenberg, Robert J. (2010). Longitudinal research: The theory, design, and analysis of change. Journal of Management, 36(1), 94-120. https://doi.org/10.1177/0149206309352110

Rasoolimanesh, S. Mostafa, Ramakrishna, Sundari, Hall, C. Michael, Esfandiar, Kourosh. and Seyfi, Siamak. (2020). A systematic scoping review of sustainable tourism indicators in relation to the sustainable development goals. Journal of Sustainable Tourism, 1-21. https://doi.org/10.1080/09669582.2020.1775621

Ruhanen, Lisa, Moyle, Char-lee. and Moyle, Brent. (2019). New directions in sustainable tourism research. Tourism Review, 74(2), 245-256. https://doi.org/10.1108/TR-12-2017-0196

Sæpórsdóttir, Anna Dóra. and Hall, C. Michael. (2020). Visitor satisfaction in wilderness in times of overtourism: A longitudinal study. Journal of Sustainable Tourism, 29(1), 123-141.

Scheyvens, Regina. (2018). Linking tourism to the sustainable development goals: a geographical perspective. Tourism Geographies, 20(2), 341-342. https://doi.org/10.1080/14616688.2018.1434818

Scheyvens, Regina, Banks, Glenn. and Hughes, Emma. (2016). The private sector and the sdgs: the need to move beyond 'business as usual.' Sustainable Development (Bradford, West Yorkshire, England), 24 (6), 371-382. https:// doi.org/10.1002/sd.1623

SCImago. (2020). Scimago Journal \& Country Rank. Retrieved from https://www.scimagojr.com/journalrank.php? category $=1409 \&$ area $=1400 \&$ type $=\mathrm{j}$.

Seraphin, Hugues, Yallop, Anca C, Seyfi, Siamak. and Hall, C. Michael. (2020). Responsible tourism: the 'why' and 'how' of empowering. In Tourism Recreation Research (p. 1). https://doi.org/10.1080/02508281.2020.1819109 
Sharif, Arshian, Saha, Shrabani, Campbell, Neil, Sinha, Avik. and Ibrahiem, Dalia M. (2020). Tourism, environment and energy: an analysis for China. Current Issues in Tourism, 23(23), 2930-2949. https://doi.org/10.1080/ 13683500.2019.1703913

Sharpley, Richard. (2020). Tourism, sustainable development and the theoretical divide: 20 years on. Journal of Sustainable Tourism, 28(11), 1932-1946. https://doi.org/10.1080/09669582.2020.1779732

Streimikiene, Delia, Svagzdiene, Biruta, Jasinskas, Edmundas. and Simanavicius, Arturas. (2020). Sustainable tourism development and competitiveness: The systematic literature review. Sustainable Development, 29(1), $259-271$. https://doi.org/10.1002/sd.2133

Sun, Ya-Yen, Cadarso, Maria Angeles. and Driml, Sally. (2020). Tourism carbon footprint inventories: A review of the environmentally extended input-output approach. Annals of Tourism Research, 82, 102928. https://doi.org/10.1016/ j.annals.2020.102928

The World Bank. (2020). International tourism, expenditures (current US\$). Retrieved from https://data.worldbank.org/ indicator/ST.INT.XPND.CD

Thomas, Karen. (2004). The research process as a journey-from positivist traditions into the realms of qualitative inquiry. In Qualitative Research in Tourism: ontologies, epistemologies and methodologies (pp. 197-214). Routledge. https://doi.org/10.4324/9780203642986-32

Tracy, Sarah. J. (2020). Qualitative research methods: Collecting evidence, crafting analysis, communicating impact (Second edition.). Wiley Blackwell.

United Nations (UN). (1992). Agenda 21 - United Nations Conference on Environment \& Development Rio de Janeiro, Brazil, 3 to 14 June 1992. Retrieved at https://www.un.org/en/events/pastevents/pdfs/Agenda21.pdf

United Nations (UN). (2015). Transforming our world: the 2030 Agenda for Sustainable Development. Retrieved from https://sustainabledevelopment.un.org/post2015/transformingourworld

United Nations (UN). (2020). Sustainable Development Goals Report 2020. Retrieved at https://unstats.un.org/sdgs/ files/report/2020/secretary-general-sdg-report-2020_EN.pdf

Vaismoradi, Mojtaba, Turunen, Hannele. and Bondas, Terese. (2013). Content analysis and thematic analysis: Implications for conducting a qualitative descriptive study. Nursing and Health Sciences, 15(3), 398-405. https://doi.org/ 10.1111/nhs. 12048

Walker, Kaye. and Moscardo, Gianna. (2014). Encouraging sustainability beyond the tourist experience: ecotourism, interpretation and values. Journal of Sustainable Tourism, 22(8), 1175-1196. https://doi.org/10.1080/ 09669582.2014 .918134

Wall, Geoffrey.. and Tao, Teresa C. H. (2008, April). Tourism as a livelihood strategy in an aboriginal community in Taiwan. In Annual Meeting of the Association of American Geographers.

World Commission on Environment and Development (WCED). (1987). Our common future: The World Commission on Environment and Development. Retrieved at https://sustainabledevelopment.un.org/content/documents/5987ourcommon-future.pdf

World Tourism Organization (UNWTO). (n.d.) Tourism in The 2030 Agenda. Retrieved from https://www.unwto.org/ tourism-in-2030-agenda

World Tourism Organization (UNWTO). (2016). Why Tourism. Retrieved from http://www.tourism4development2017.org/ why-tourism/

World Tourism Organization. (2017). 2017 is the international year of sustainable tourism for development. Retrieved from https://www.unwto.org/archive/global/press-release/2017-01-03/2017-international-year-sustainable-tourismdevelopment

World Tourism Organization. (2020, Jan 19). World tourism barometer Nº 18 JANUARY 2020. Retrieved from https:// www.unwto.org/world-tourism-barometer-n18-january-2020

Yan, Jiong. and Barkmann, Jan. (2006). Sustainable production and consumption in the domestic Chinese tourism market: The sceptics' challenge for sustainable tourism in the southwestern China biodiversity hotspot. In Sustainable Consumption and Production: Opportunities and Challenges Conference. Wuppertal: SCORE. 
Zolfani, Sarfaraz Hashemkhani, Sedaghat, Maedeh, Maknoon, Reza. and Zavadskas, Edmundas Kazimieras. (2015). Sustainable tourism: A comprehensive literature review on frameworks and applications. Economic ResearchEkonomska Istrazivanja, 28(1), 1-30. https://doi.org/10.1080/1331677X.2014.995895 Hospitality. 1(3), 1-20. doi: 10.51483/IJTH.1.3.2021.1-20. 